\title{
Induction of Systemic Acquired Resistance Aids Restoration of Tree Health in Field-Grown Pear and Apple Diseased with Fire Blight
}

\author{
Kenneth B. Johnson and Todd N. Temple, Department of Botany and Plant Pathology, Oregon State University, Corvallis 97331-2902
}

\begin{abstract}
Induction of systemic acquired resistance as a therapeutic aid to restoration of tree health was evaluated in 3- to 14-year-old pear and apple trees diseased with fire blight. Acibenzolar-S-methyl (ASM) was applied to diseased trees in late spring near the time of removal of primary fire blight cankers, which had originated from floral infection. Suspensions of ASM ( 7.5 to $22.5 \mathrm{~g}$ of active ingredient per liter plus silicone surfactant) were painted onto a 30 - to $45-\mathrm{cm}$ length of branch tissue immediately below primary pruning cuts or sprayed onto an 80 - to 100 -cm length of central trunk. In some experiments, a second ASM treatment was made in late June to early July in conjunction with secondary pruning of redeveloped cankers. After pruning primary cankers, effects of ASM were measured

by assessing weight and length of secondary cankers that were the result of fire blight redevelopment. Over 5 years of field experiments, trees that received an ASM treatments yielded 62\% less diseased wood at the time of secondary and tertiary canker removal compared with non-ASMtreated trees. Moreover, tree mortality and proportion of pruning cuts where fire blight redeveloped were reduced by ASM. Induction of systemic acquired resistance could prove practical as an aid to pruning therapy in young, fire-blight-susceptible pear and apple trees where, after canker removal, disease symptoms frequently redevelop owing to residual cells of the pathogen distributed within symptomless portions of the tree.
\end{abstract}

Fire blight, caused by Erwinia amylovora, is an important disease of pear and apple trees, especially in the first decade after planting. After infection of a flower or vegetative shoot (Johnson 2000; Johnson and Stockwell 1998), the resulting disease symptoms in young trees can expand rapidly into indeterminate "running" cankers, which can be severely damaging in spite of the use of therapeutic pruning to remove them from the trees (Norelli et al. 2003; van der Zwet and Beer 1992). In young trees, the act of pruning removes symptomatic branches and limbs but fire blight frequently redevelops at pruning cuts or elsewhere in the tree owing to residual cells of the pathogen distributed within symptomless portions of the tree, even when pruning cuts are made a recommended distance (e.g., 15 to $30 \mathrm{~cm}$ ) below the proximal edge of the expanding canker (Steiner 2000; Thomson 2000; van der Zwet and Beer 1992). This redevelopment of expanding, running cankers leads to additional rounds of pruning diseased branches and, potentially, to tree death. Moreover, in young apple trees, residual pathogen cells sometimes cause fire blight at the graft union if the infected scion has been joined to a highly susceptible rootstock cultivar such as 'M.9' or 'M.26' (Momol et al. 1998; Norelli et. al 2003). This phase of the disease, termed "rootstock blight", generally kills the tree (Johnson 2000; Momol et al. 1998; Norelli et al. 1999, 2003).

Systemic acquired resistance (SAR) is an evolved defense system of plants that is triggered in response to abiotic stress or pathogen infection (Fu and Dong 2013). This induced defense system is initiated by a salicylic-acid-mediated signaling process that leads to systemic accumulation of gene products termed "pathogenesis-related" (PR) proteins, which are hypothesized to contribute to the resistance response. Induction of SAR in plants has been studied for multiple decades (Fu and Dong 2013; Kuc and Richmond 1977; Tally et al. 1999; Walters and Fountaine 2009) and the literature has several examples of bacterial diseases of fruit trees being suppressed by exogenous induction of SAR with chemicals that mimic salicylic acid (Aćimović et al. 2015; Brisset et al. 2000; Francis et al. 2009; Maxson-Stein et al. 2002). Among these studies, a consistent observation has been that the chemical, acibenzolar-S-methyl (ASM), induces SAR in fruit trees as evidenced by a reduced incidence of

Corresponding author: K. Johnson; E-mail: johnsonk@science.oregonstate.edu

Accepted for publication 1 March 2017.

(c) 2017 The American Phytopathological Society infection and increased expression of PR-proteins in leaves. Furthermore, in field-grown fruit trees, several methods of ASM application have induced SAR including foliar sprays, root drenches and trunk injection (Aćimović et al. 2015; Graham and Myers 2011; Johnson et al. 2016; Maxson-Stein et al. 2002).

In exploratory greenhouse experiments, we evaluated the effect of SAR induction with ASM as a therapy to slow expansion of running fire blight cankers in potted, 1-year-old pear and apple trees (Johnson and Temple 2016). After inoculation with E. amylovora, ASM applied as a concentrated paint to the tree trunk, pot drench, or foliar spray were each shown to suppress fire blight canker expansion in greenhouse-grown trees. Trunk paints of ASM, in particular, showed a consistent and long-lasting (2-month) induction of enhanced PR-protein expression in leaves. A conclusion of the study was that the branch or trunk paint method placed ASM near where it was most needed to suppress fire blight therapeutically and, potentially, the method would be adaptable to specific disease management situations in an orchard (e.g., individual tree therapy and disease location within a tree). In preliminary field experiments in 2011, ASM applied as a soil drench or foliar spray was not effective as a postinfection therapy for suppression of running fire blight cankers (K. Johnson and T. Temple, unpublished data). In contrast, in the same field experiments, paints of ASM applied locally to symptomless branch tissue below a pruning cut reduced the amount of disease that subsequently redeveloped at the cuts. The purpose of this study was to investigate ASM paints used in conjunction with pruning as a therapy for restoration of health in young pome fruit trees diseased with fire blight.

\section{Materials and Methods}

Field plantings. Studies on use of ASM for postinfection fire blight suppression were conducted from 2012 to 2016 in experimental field plantings located at Oregon State University's Botany and Plant Pathology Field Laboratory near Corvallis. Soils in plot areas consisted of either a Chehalis silty clay loam or a Camas sandy loam. Most experiments were done in two plantings of Bosc pear, which were established in 2009 and 2011: Pyrus communis L. 'Golden Russet Bosc' (100 trees) and 'Bronze Beauty Bosc' (180 trees), respectively, on ' $\mathrm{OHxF} 97$ ' rootstock. In addition, single experiments were conducted in a 200-tree planting of apple established in 2014 (Malus $\times$ domestica Borkh. 'Brookfield Gala' on 'Budagovsky 118' rootstock), a 100-tree pear orchard established in 2000 (P. communis 'Bartlett' on OHxF 97 rootstock, 14 years old at time of the experiment), and in 100-tree outdoor container planting of pear established in 2013 (P. communis 'Concorde' on 'OHxF 87' rootstock in 19-liter 
pots that contained Sunshine LA4 $\mathrm{P}$ growth medium [pH 5.6; SunGro Horticulture, Agawam, MA]). All cultivars are highly susceptible to fire blight (van der Zwet and Beer 1992). At time of planting, trees were received in late March in a dormant, bare-root condition from commercial nurseries. Bosc pear and Gala apple trees were planted at a spacing of $1 \mathrm{~m}$ between trees and $3 \mathrm{~m}$ between rows. Trees in the 14-year-old Bartlett pear orchard were spaced 6 by $6 \mathrm{~m}$ between and within rows. At planting, each tree received $200 \mathrm{~g}$ of $10-10-10$ (N-P-K) fertilizer mixed into the planting hole and, each subsequent spring, trees were top dressed with 30 to $65 \mathrm{~g}$ of ammonium nitrate (21-0-0, N-P-K, nitrogen units $=40$ to $85 \mathrm{~kg} / \mathrm{ha}$; Wilbur Ellis Co., Aurora, CO). Rows of trees were grown in 2 -m-wide vegetation-free strips maintained by hand weeding in year of establishment, and by a combination of herbicides and hand weeding in subsequent seasons. During summer, field plantings of the young trees were irrigated weekly from solid-set overhead sprinklers $(2.5 \mathrm{~cm} /$ irrigation); potted Concorde pear trees were watered at least twice a week and the 14-year-old Bartlett pear orchard was irrigated monthly (5 cm/irrigation). In April, depending on the frequency of rainy weather, pear and apple scab (Venturia spp.) were suppressed with one to three treatments of mancozeb (Dithane DF at $3.4 \mathrm{~kg} / \mathrm{ha}$; Dow AgroSciences, Indianapolis, IN) applied with an air-blast sprayer (935 liters/ha at $862 \mathrm{kPa}$ ).

Basic experimental protocol. Experiments were initiated by first establishing fire blight in an orchard planting and then superimposing a randomized complete block design onto diseased trees. At full bloom, 50 to 150 trees in a planting were inoculated with E. amylovora $\left(1 \times 10^{9} \mathrm{CFU} / \mathrm{ml}\right)$ by misting four to six flower clusters to runoff with a 0.5 -liter, hand-held, trigger sprayer. Inoculum suspensions were prepared by resuspending titred, freeze-dried cells of the pathogen in distilled water (Stockwell et al. 1998). Fire blight infections were allowed to develop for 5 to 8 weeks after inoculation. At this time (May or early June), the plantings were mapped for infections per tree. Mapped disease data were used to create experimental blocks of trees with similar numbers of infections per tree, which was followed by random assignment of treatments to singletree plots within each block. At the time of the primary pruning of cankers, only trees with fire blight symptoms were incorporated into the experimental design. A preliminary experiment in 2011 demonstrated a high level of variability in how fire blight redevelops in individual trees after pruning. Consequently, for the 10 individual orchard experiments conducted from 2012 to 2016, the number of replicated, complete blocks in an experiment ranged from 10 to 49 , with an average of 22 replications per experiment (Table 1).

Following completion of the experimental design, a primary pruning was accomplished by removing all cankers from each tree with hand-held shears or a horticultural saw at a distance of 15 to $20 \mathrm{~cm}$ below the proximal margin of canker symptoms. In most experiments, paint treatments of ASM were applied immediately after primary pruning. Timings and rates of ASM paint treatments are shown

Table 1. Details of experiments conducted from 2012 to 2016 to evaluate acetyl-S-methyl (ASM) treatments as an aid to restoration of pear and apple tree health in fire blight-diseased field plantings located near Corvallis, OR

\begin{tabular}{|c|c|c|c|c|c|c|c|}
\hline Cultivar, age, year ${ }^{\mathrm{a}}$ & Inoc $^{b}$ & Reps & Treatment $^{c}$ & Cankers $( \pm S E)^{d}$ & Rate (g/liter) $)^{\mathbf{e}}$ & Applied $(g)^{\mathbf{f}}$ & Dates of cuts (ASM applied)g \\
\hline \multirow[t]{3}{*}{ Bosc, 4L, 2012} & 23 April & 15 & Cut-only & $3.6(0.5)$ & $\ldots$ & $\ldots$ & 6 June, 27 June, 4 October \\
\hline & $\ldots$ & 10 & Cut and brush, $\mathrm{P}$ & $3.6(0.5)$ & 15 & 0.10 & (7 June, 27 June) \\
\hline & $\ldots$ & 10 & Cut and brush, $\mathrm{P}$ & $3.1(0.5)$ & 22.5 & 0.15 & (7 June, 27 June) \\
\hline \multirow[t]{2}{*}{ Bartlett, 4L, 2013} & 9 April & 14 & Cut-only & $14.5(2.0)$ & $\ldots$ & $\ldots$ & 5 June, 12 October \\
\hline & $\ldots$ & 14 & Cut and brush, $\mathrm{P}$ & $10.9(1.6)$ & 15 & 0.10 & (5 June) \\
\hline \multirow[t]{4}{*}{ Bosc, 6L, 2014} & 9 April & 18 & Cut-only & $26.4(3.6)$ & $\ldots$ & $\ldots$ & 23 May*, 2 July, 12 September \\
\hline & $\ldots$ & 18 & Cut and spray, $\mathrm{P}$ & $25.3(3.4)$ & 15 & 0.75 & (2 May, 2 July) \\
\hline & $\ldots$ & 19 & Cut and spray- $\mathrm{P}$ & $31.3(6.0)$ & 15 & 0.75 & (16 May, 2 July) \\
\hline & $\ldots$ & 19 & Cut and spray, $\mathrm{P}$ & $35.1(4.0)$ & 7.5 & 0.33 & (16 May, 2 July) \\
\hline \multirow{4}{*}{ Bosc, 4L, 2014} & 10 April & 23 & Cut-only & $20.2(2.8)$ & $\ldots$ & $\ldots$ & 28 May*, 2 July,15 September \\
\hline & $\ldots$ & 22 & Cut and spray, $\mathrm{P}$ & $20.1(2.8)$ & 15 & 0.75 & (2 May, 2 July) \\
\hline & $\ldots$ & 22 & Cut and spray, $\mathrm{P}$ & $21.5(2.7)$ & 15 & 0.75 & (16 May, 2 July) \\
\hline & $\ldots$ & 22 & Cut and spray, $\mathrm{P}$ & $19.6(2.6)$ & 15 & 0.75 & (28 May, 2 July) \\
\hline \multirow[t]{2}{*}{ Bosc, 7L, 2015} & 6 April & 22 & Cut-only & $3.2(0.4)$ & $\ldots$ & $\ldots$ & 21 May, 28 September \\
\hline & $\ldots$ & 22 & Cut and spray, $\mathrm{P}$ & $3.2(0.4)$ & 15 & 0.75 & (21 May, 22 June) \\
\hline \multirow[t]{2}{*}{ Bosc, 5L, 2015} & 6 April & 23 & Cut-only & $3.2(0.5)$ & $\ldots$ & $\ldots$ & 21 May, 8 October \\
\hline & $\ldots$ & 23 & Cut and spray, $\mathrm{P}$ & $3.2(0.5)$ & 15 & 0.75 & (21 May) \\
\hline \multicolumn{8}{|l|}{ Potted } \\
\hline \multirow[t]{3}{*}{ Concorde, 3L, 2015} & 6 April & 20 & Cut-only & $4.3(0.6)$ & r & $\ldots$ & 7 May, 22 June, 28 September \\
\hline & $\ldots$ & 20 & Cut and spray, $\mathrm{P}$ & $4.3(0.6)$ & 15 & 0.10 & (7 May) \\
\hline & $\ldots$ & 20 & Cut and spray, $\mathrm{P}$ & $4.3(0.7)$ & 15 & 0.10 & (7 May, 22 June) \\
\hline \multirow[t]{2}{*}{ Bosc, 8L, 2016} & 1 April & 35 & Cut-only & $94(9.8)$ & $\ldots$ & $\ldots$ & 9 May, 28 June, 28 September \\
\hline & $\ldots$ & 35 & Cut and spray, B & $85(9.8)$ & 15 & 0.75 & (9 May, 28 June) \\
\hline \multirow[t]{4}{*}{ Bosc, 6L, 2016} & 1 April & 19 & Cut-only & $28.9(4.0)$ & $\ldots$ & $\ldots$ & 2 May, 27 June, 28 September \\
\hline & $\ldots$ & 19 & Cut and spray, $\mathrm{N}$ & $29.0(4.1)$ & 15 & 0.75 & (2 May, 27 June) \\
\hline & $\ldots$ & 19 & Cut and spray, $\mathrm{P}$ & $28.6(3.9)$ & 15 & 0.75 & (2 May, 27 June) \\
\hline & $\ldots$ & 19 & Cut and spray, B & $28.5(4.0)$ & 15 & 0.75 & (2 May, 27 June) \\
\hline \multirow[t]{2}{*}{ Gala, 3L, 2016} & 7 April & 49 & Cut-only & $7.0(0.6)$ & $\ldots$ & $\ldots$ & 10 May, 27 June, 28 September \\
\hline & $\ldots$ & 49 & Cut and spray, B & $8.0(0.5)$ & 15 & 0.30 & (10 May, 27 June) \\
\hline
\end{tabular}

a Tree age abbreviations: $3 \mathrm{~L}, 4 \mathrm{~L} \ldots 8 \mathrm{~L}=$ third-leaf, fourth-leaf...eighth-leaf, respectively.

${ }^{\mathrm{b}}$ Date of inoculation. Four to six flower clusters per tree were misted with a suspension of Erwinia amylovora strain Ea153 N at $1 \times 10^{9} \mathrm{CFU} / \mathrm{ml}$.

${ }^{\mathrm{c}}$ In all treatments, fire blight symptoms were removed from trees by pruning. In conjunction with pruning, ASM plus $1 \%$ silicone surfactant was applied by foam brush to cylinders of symptomless branch tissue 12 to $18 \mathrm{~cm}$ below removed cankers (2012 and 2013) or applied with a hand-held sprayer to a 1-m length of the central trunk of each tree (2014 to 2016). Letter following ASM treatment denotes surfactant: Pentra-Bark (P), Break-Thru (B)m or no surfactant (N).

${ }^{\mathrm{d}}$ Cankers per tree \pm standard error (SE) at first cut. In mid-May to early June, after primary fire blight infections were apparent but before primary pruning of cankers, diseased trees were mapped and assigned to experimental blocks based on number of infections per tree.

e ASM rate in grams of active ingredient per liter.

${ }^{\mathrm{f}}$ Approximate amount of ASM applied per branch cylinder or central trunk.

${ }^{\mathrm{g}}$ For 2014 experiments marked with an asterisk (*), date of primary pruning of cankers was 23 (sixth-leaf Bosc) or 28 May (fourth-leaf Bosc), but ASM was applied to the central trunk on the dates indicated. 
in Table 1. For experiments in 2012 and 2013, ASM and silicone surfactant ( $1 \%$ alkylphenol ethoxylate, polysiloxane polyether copolymer, and propylene glycol; Pentra-Bark, Quest Products Corp., Linwood, KS) were applied with a flat foam brush ( 5 by $7 \mathrm{~cm}$, model 140-2; Solo Horton, Torrington, CT) to 30 to $45 \mathrm{~cm}$ of branch length below each pruning cut; the complete cylinder of branch was painted with the ASM suspension. The purpose of the surfactant was to aid wetting and penetration of ASM into bark tissue (Garbelotto et al. 2007, Johnson and Temple 2016). For experiments in 2014 to 2016, ASM and surfactant were applied to an 80- to 100-cm length of the central leader with a 1-liter, hand-held pump sprayer (model 418; Solo Inc., Newport News, VA). Two opposing sides of trunk were treated with the ASM suspension, with the cone-shielded nozzle of the sprayer positioned a distance of $1 \mathrm{~cm}$ from the trunk surface. Approximate amounts of ASM applied below each cut (2012 to 2013) or onto the central leader (2014 to 2016) are shown in Table 1.

After primary pruning and initial ASM treatment, trees were evaluated for redevelopment of fire blight in late June and again in September or October. Based on the amount of disease observed in June, in some experiments (Table 1), a secondary pruning (first canker removal post-ASM) was imposed at this time whereas, in other experiments with lesser amounts of redeveloped fire blight, the secondary pruning was delayed until September or October. For secondary pruning of cankers in June, ASM treatments were reapplied only to trees from which cankers were removed, and experiments that received a secondary pruning in June also received a tertiary pruning in September or October. Secondary and tertiary pruning cuts also were made 15 to $20 \mathrm{~cm}$ below the proximal canker margin, and weight and length of diseased branch tissues removed were recorded to assess effects of the ASM treatments.

Permutations in ASM paint treatments. Because of the need to maintain a high number of experimental replications, individual complete-block design experiments could accommodate only two to four treatments. All experiments included the two treatments "cut only" and "cut in combination with ASM". Additional permutations of the ASM treatment (Table 1) were included in some experiments, including a higher or lower concentration of the chemical, varied timing of SAR induction in association with the primary pruning of cankers, and the presence of and specific surfactant mixed with ASM. Specifically, based on greenhouse results (Johnson and Temple 2016), ASM at $15 \mathrm{~g}$ of active ingredient (a.i.) per liter was tested in all experiments; however, we also tested $22.5 \mathrm{~g}$ a.i./liter in fourth-leaf Bosc pear in 2012 and $7.5 \mathrm{~g}$ a.i./liter in sixth-leaf Bosc pear in 2014. Also in 2014, in the two field plantings of Bosc pear, ASM (15 g a.i./liter) was painted onto trees on 2 May, 16 May, or 28 May but primary pruning for all of these treatments and the cutonly control occurred on the same day: 23 May in one experimental plot and 28 May in the other. In 2015, in potted Concorde pear, we compared one ASM treatment, which was associated with the primary cut in May, with two ASM treatments, which were associated with primary and secondary cuts in May and July. The surfactant amendment to ASM was evaluated in sixth-leaf Bosc pear in 2016; treatments were no surfactant, 1\% Pentra-Bark, and 1\% Break-Thru S 240 (polyethermodified polysiloxane; Evonik Corp., Richmond, VA).

Data analysis. Among experiments, after primary pruning, redevelopment of fire blight symptoms occurred in a high proportion of cut-only control trees but, within individual experiments, the severity of redeveloped disease was highly variable among individual trees (i.e., the full range of no disease redevelopment to complete tree death occurred in the cut-only control of each experiment). Consequently, for individual experiments, both parametric and nonparametric statistical tests to evaluate effects of ASM treatment frequently resulted in nonsignificant $P$ values in spite of a consistent effect of the treatment being observable in graphical arrays of individual trees ranked by the severity of redeveloped fire blight. Therefore, for individual experiments, we limited the analysis to presentation of these rank-order graphical arrays and to computation of the following summary statistics: percent trees with redeveloped fire blight, percent trees with size reduced by $>75 \%$ after pruning redeveloped fire blight, percent trees killed by fire blight, and relative canker weight and length for combined secondary and tertiary pruning cuts from ASM-treated trees. Relative canker weight and length were computed by dividing the experimental sum for ASMtreated trees by the sum for the cut-only control (Johnson and Temple 2016). Values of these summary statistics from individual experiments were used as a data set to compare by two-sample $t$ test the cut in combination with ASM (15 g a.i./liter, $n=16)$ to the cut-only control $(n=10)$.

\section{Results}

Inoculation of four to six flower clusters of pear or apple with E. amylovora resulted in fire blight in each of the experiments (Table 1). Relative success of inoculation, however, varied among experiments owing to bloom density and conduciveness of weather for secondary dispersal of the pathogen and subsequent infection of noninoculated flowers. For example, in 2015, experimental trees in fifth- and seventh-leaf Bosc pear plantings averaged 3.2 primary infections, which was slightly less than the number of inoculated flower clusters per tree; whereas, in 2016, the eighth-leaf Bosc pear planting averaged 89 primary infections per tree owing to secondary pathogen dispersal after inoculation. Among experiments, the incubation period from inoculation to symptom expression ranged from 2 to 4 weeks; therefore, at the time of the primary pruning of cankers (5 to 8 weeks after inoculation), nearly all primary infections had developed symptoms. Assignment of trees to experimental blocks based on number of primary infections per tree minimized differences in initial infection incidence among treatments at the time of primary pruning of cankers (Table 1).

In cut-only controls, after primary pruning of cankers, fire blight symptoms redeveloped on an average of 43 to $96 \%$ of trees in each experiment (Table 2). For those experiments in which secondary pruning of cankers was done in late June or early July, redevelopment of fire blight symptoms after this cut ranged from 20 to $67 \%$ (data not shown). Within experiments, the severity of redeveloped fire blight was highly variable among individual trees. For example, for the cutonly control, the full range of severity from no disease redevelopment to complete tree death as a result of fire blight occurred in every experiment (Table 2). Ranking of individual trees of the cut-only control by severity of redeveloped fire blight highlighted the variability among trees within each experiment (Fig. 1). This ranking also demonstrated that high variability in the amount of redeveloped disease per tree was a consistent feature of all experiments.

Rankings of individual trees by severity of redeveloped fire blight also revealed variability among trees that received ASM; however, canker weights after the SAR treatment were consistently smaller than those observed in the cut-only control (Fig. 1). Averaged across experiment, relative canker weight on ASM-treated trees was reduced significantly $(P \leq 0.01)$ to $38 \%$ of the weights from the cut-only controls (Table 3). Similarly, for ASM-treated trees, the proportion of trees killed by fire blight $(14 \%)$ was significantly $(P \leq 0.05)$ smaller than observed in the cut-only control (25\%) (Table 3$)$. ASM treatment in conjunction with pruning also reduced the proportion of trees in which fire blight redeveloped after primary pruning of cankers from 77 to $63 \%$ but this difference was not significant $(P>0.05)$.

In general, permutations in the ASM treatment in the field experiments provided results consistent with expectations based on prior results from greenhouse studies (Johnson and Temple 2016). For example, as observed previously, reducing the rate of ASM from $15 \mathrm{~g}$ a.i./liter to half this amount reduced the effect of the SAR treatment (Table 2, sixth-leaf Bosc pear, 2014) but increasing the rate to $22.5 \mathrm{~g}$ a.i./liter resulted in approximately the same treatment effect as observed with ASM at $15 \mathrm{~g}$ a.i./liter (Table 2, fourth-leaf Bosc pear, 2012). Similarly, in both 2014 experiments (Table 2), applying ASM early (2 May) provided a larger reduction in severity of redeveloped fire blight than applying the material 2 weeks later (16 May). In contrast to greenhouse results where a sequence of two ASM treatments was more suppressive than a single treatment, roughly equivalent treatment effects were observed from one or two ASM treatments onto potted Concorde pear trees (Table 2, 2015 experiment) although, in this experiment, the proportion of trees in which fire blight redeveloped after primary pruning of cankers was relatively low. Furthermore, the 
addition of surfactant to ASM resulted in similar reductions in redeveloped canker weights (67\% less than the cut-only control) compared with ASM treatment without a surfactant $(64 \%$ less than the cutonly control) (Table 2, sixth-leaf Bosc pear, 2016) although, at time of treatment, bark tissue of trees that received ASM with surfactant appeared appreciably wetter after spraying (with less runoff) than bark of trees that received ASM only.

\section{Discussion}

As shown by the fire-blight-induced death of some trees in each of the experiments, this study confirmed the difficulty of restoring health of young, diseased pear and apple trees during summer with the practice of therapeutic pruning. This difficulty is attributed to proximal, internal migration of the pathogen in branches ahead of the expanding, symptomatic canker, which results in residual cells being left in trees after pruning cuts have been made (Steiner 2000). In a review of invasion of woody tissues by E. amylovora, Billing (2011) concluded that the primary route for pathogen migration is via intercellular spaces of parenchymal bark tissue, with mature xylem vessels of stem tissue providing a secondary migration route. More recently, Koczan et al. (2011) reported that E. amylovora produces a biofilm in xylem and that pathogen genes that regulate biofilm production contribute to its ability to migrate inside a tree. With regard to fire blight redevelopment after primary canker removal, the relative significance of routes of pathogen migration within a tree are not well understood. Also poorly understood are host conditions that allow residual pathogen cells to reinitiate disease visa-vis those conditions that cause cessation of canker expansion and attrition of the residual pathogen population. This poor understanding is illustrated by conflicting experiences after summer pruning of fire blight infections from trees (Clarke et al. 1991; Covey and Fischer 1990; Shtienberg et al. 2003; Toussaint and Philion 2008), although pruning out fire blight infections early and quickly is the most common recommendation (Covey and Fischer 1990; Steiner 2000; Thomson 2000; Toussaint and Philion 2008). In our data, after primary pruning of the cut-only controls, canker redevelopment and subsequent disease severity were highly variable among individual trees, with this variability being a consistent feature of all experiments. We speculate that multiple factors contribute to this variability, including density of residual pathogen populations after pruning, differences in vigor and nutritional status among individual trees, and smaller-scale considerations such as branch age and location of primary infections within trees. The fact that ASM produced a treatment effect indicates that host defense induction (or lack thereof) is also a potential contributor to variability in canker redevelopment.

Highly variable canker redevelopment and severity also were observed in trees that received ASM treatments but on a reduced scale compared with cut-only controls. Over all experiments, compared with controls, reductions in the proportion of trees in which fire blight redeveloped was a relatively small (nonsignificant) component of observed

Table 2. Results of experiments conducted from 2012 to 2016 to evaluate acetyl-S-methyl (ASM) treatments as an aid to restoration of pear and apple tree health in fire blight-diseased field plantings located near Corvallis, OR

\begin{tabular}{|c|c|c|c|c|c|c|c|}
\hline Cultivar, age, year ${ }^{a}$ & Rate (g/liter) ${ }^{b}$ & Applied $^{\mathrm{c}}$ & Blight $(\%)^{d}$ & Weight $(\mathrm{kg} \pm \mathrm{SE})^{\mathrm{e}}$ & Length $(m \pm S E)^{f}$ & Size reduced $(\%)^{\mathrm{g}}$ & Killed $(n)^{\text {h }}$ \\
\hline \multirow{3}{*}{ Bosc, 4L, 2012} & $\ldots$ & $\mathrm{COC}$ & 80 & $1.7(0.5)$ & $1.7(0.3)$ & 27 & 3 \\
\hline & $15, \mathrm{P}$ & 7 June, 27 June & 40 & $0.8(0.6)$ & $0.8(0.5)$ & 10 & 2 \\
\hline & $22.5, \mathrm{P}$ & 7 June, 27 June & 60 & $0.7(0.4)$ & $1.0(0.5)$ & 0 & 1 \\
\hline \multirow[t]{2}{*}{ Bartlett, 4L, 2013} & $\ldots$ & $\mathrm{COC}$ & 88 & $9.4(2.0)$ & $2.67(0.77)$ & 25 & 2 \\
\hline & $15, \mathrm{P}$ & 5 June & 88 & $5.4(1.6)$ & $1.46(0.44)$ & 6 & 0 \\
\hline \multirow[t]{4}{*}{ Bosc, 6L, 2014} & $\ldots$ & $\mathrm{COC}$ & 89 & $1.4(0.4)$ & $1.01(0.26)$ & 22 & 3 \\
\hline & $15, \mathrm{P}$ & 2 May, 2 July & 78 & $0.3(0.1)$ & $0.15(0.05)$ & 11 & 2 \\
\hline & $15, \mathrm{P}$ & 16 May, 2 July & 89 & $1.0(0.3)$ & $0.65(0.20)$ & 33 & 3 \\
\hline & $7.5, \mathrm{P}$ & 16 May, 2 July & 84 & $1.8(0.5)$ & $0.73((0.14)$ & 22 & 5 \\
\hline \multirow[t]{4}{*}{ Bosc, 4L, 2014} & $\ldots$ & $\mathrm{COC}$ & 87 & $1.5(0.3)$ & $0.68(0.13)$ & 57 & 9 \\
\hline & $15, \mathrm{P}$ & 2 May, 2 July & 55 & $0.5(0.2)$ & $0.39(0.13)$ & 27 & 3 \\
\hline & $15, \mathrm{P}$ & 16 May, 2 July & 64 & $0.8(0.2)$ & $0.29(0.08)$ & 32 & 5 \\
\hline & $15, \mathrm{P}$ & 28 May, 2 July & 86 & $0.8(0.2)$ & $0.41(0.08)$ & 36 & 6 \\
\hline \multirow[t]{2}{*}{ Bosc, 7L, 2015} & $\ldots$ & $\mathrm{COC}$ & 43 & $1.9(0.7)$ & $0.28(0.11)$ & 24 & 5 \\
\hline & $15, \mathrm{P}$ & 21 May, 22 June & 19 & $0.2(0.1)$ & $0.12(0.06)$ & 0 & 0 \\
\hline \multirow[t]{2}{*}{ Bosc, 5L, 2015} & $\ldots$ & $\mathrm{COC}$ & 48 & $1.4(0.5)$ & $0.34(0.10)$ & 13 & 2 \\
\hline & $15, \mathrm{P}$ & 21 May & 9 & $0.1(0.1)$ & $0.04(0.03)$ & 0 & 0 \\
\hline \multirow[t]{3}{*}{ Concorde, 3L, 2015} & $\ldots$ & $\mathrm{COC}$ & 45 & $0.13(0.04)$ & $0.38(0.12)$ & 35 & 9 \\
\hline & $15, \mathrm{P}$ & 7 May & 25 & $0.02(0.01)$ & $0.01(0.01)$ & 10 & 2 \\
\hline & $15, \mathrm{P}$ & 7 May, 22 June & 15 & $0.01(0.01)$ & $0.01(0.01)$ & 10 & 2 \\
\hline \multirow[t]{2}{*}{ Bosc, 8L, 2016} & $\ldots$ & $\mathrm{COC}$ & 94 & $2.1(0.5)$ & $1.96(0.26)$ & 27 & 9 \\
\hline & 15 , B & 10 May, 28 June & 66 & $1.0(0.3)$ & $0.90(0.19)$ & 9 & 3 \\
\hline \multirow[t]{4}{*}{ Bosc, 6L, 2016} & $\ldots$ & $\mathrm{COC}$ & 95 & $4.5(0.8)$ & $4.35(0.61)$ & 58 & 11 \\
\hline & $15, \mathrm{~N}$ & 2 May, 27 June & 95 & $1.6(0.3)$ & $2.46(0.36)$ & 32 & 6 \\
\hline & $15, \mathrm{P}$ & 2 May, 27 June & 95 & $1.7(0.3)$ & $2.79(0.34)$ & 26 & 5 \\
\hline & $15, \mathrm{~B}$ & 2 May, 27 June & 100 & $1.3(0.4)$ & $2.47(0.42)$ & 26 & 5 \\
\hline \multirow{2}{*}{ Gala, 3L, 2016} & $\ldots$ & $\mathrm{COC}$ & 96 & $1.3(0.2)$ & $0.81(0.07)$ & 14 & 2 \\
\hline & $15, \mathrm{~B}$ & 10 May, 27 June & 85 & $0.3(0.1)$ & $0.51(0.06)$ & 4 & 0 \\
\hline
\end{tabular}

a Cultivars: Bosc, Bartlett, and Concorde pear plus Gala apple. Tree age abbreviations: $3 \mathrm{~L}, 4 \mathrm{~L} \ldots 8 \mathrm{~L}=$ third-leaf, fourth-leaf...eighth-leaf, respectively.

${ }^{\mathrm{b}}$ ASM rate in grams of active ingredient per liter. In all treatments, fire blight symptoms were removed from trees by pruning. In conjunction with pruning, ASM plus $1 \%$ silicone surfactant was applied by foam brush to cylinders of symptomless branch tissue 12 to $18 \mathrm{~cm}$ below removed cankers (2012 and 2013) or applied with a hand-held sprayer to a 1-m length of the central trunk of each tree (2014 to 2016). Letter following rate of ASM denotes surfactant: Pentra-Bark (P), BreakThru (B), or no surfactant $(\mathrm{N})$.

${ }^{c}$ For secondary pruning of cankers in late June to early July, ASM was reapplied only to trees on which fire blight symptoms had redeveloped. Cut-only control (COC) with data pertaining to this control treatment indicated in bold.

d Percentage of trees in which fire blight redeveloped after the primary cut.

${ }^{\mathrm{e}}$ Canker weight in kilograms \pm standard error (SE) per tree after secondary and tertiary cuts. Secondary and tertiary pruning cuts to remove fire blight cankers occurred in early summer (late June or early July) and at the end of the season (September or October).

${ }^{f}$ Canker length in meters \pm SE per tree after secondary and tertiary cuts.

$\mathrm{g}$ Percentage of trees with size reduced $>75 \%$, assessed at time of the final pruning of cankers (September or October).

${ }^{\mathrm{h}}$ Number of trees killed by fire blight, assessed at time of the final pruning of cankers (September or October). 
effects of ASM. This indicates that ASM-treated trees that exhibited either no or minor canker redevelopment probably did not benefit from the treatment. In contrast, at intermediate and severe degrees of canker redevelopment, the magnitude of diseased wood pruned from ASMtreated trees was nearly always smaller than the comparable rank order tree in the cut-only control (Fig. 1). From the statistical analysis, we concluded that suppressed size of redeveloped cankers was the most important effect of SAR therapy. An intermediate effect of ASM was a $40 \%$ reduction in disease-induced tree death, which might prove to be the most practical consideration in whether or not to employ SAR therapy as a management tool (Norelli et al. 1999, 2003).

To our knowledge, this is the first utilization of SAR induction as a therapy to aid health restoration of a diseased, field-grown tree. This concept was first explored in greenhouse studies (Johnson and Temple 2016), where we observed superior effectiveness of ASM trunk paints on running fire blight cankers compared with root drenches or foliar spraying and, at the same time, determined effective rates of application. We also found that ASM applied as a trunk paint showed a consistent and long-lasting (2-month) induction of enhanced PR protein expression in leaves. In the context of suppressing canker expansion, the greenhouse studies revealed that early treatment of ASM was more effective than later treatments, and two treatments were more effective than one. In general, permutations of ASM treatments that we evaluated in the field plantings were in agreement with greenhouse results
Table 3. Means of disease response variables from 10 experiments conducted from 2012 to 2016 to evaluate treatment with acetyl-S-methyl (ASM) as an aid to restoration of pear and apple tree health in fire blight-diseased field plantings located near Corvallis, OR

\begin{tabular}{|c|c|c|c|}
\hline \multirow[b]{2}{*}{ Disease response variable } & \multicolumn{2}{|c|}{ 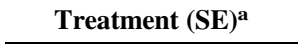 } & \multirow[b]{2}{*}{$P^{\mathbf{b}}$} \\
\hline & Control & Cut + ASM & \\
\hline $\begin{array}{l}\text { Trees that redeveloped fire blight after } \\
\text { primary pruning of cankers }(\%)\end{array}$ & $76.5(7.0)$ & $62.9(8.1)$ & ns \\
\hline Trees with size reduced $>75 \%(\%)^{\mathrm{c}}$ & $30.3(4.4)$ & $17.0(3.5)$ & $\leq 0.05$ \\
\hline Trees killed by fire blight $(\%)^{\mathrm{c}}$ & $25.4(4.2)$ & $14.0(2.4)$ & $\leq 0.05$ \\
\hline Relative canker yield $(\%)^{\mathrm{d}}$ & 100 & $38.2(4.9)$ & $\leq 0.01$ \\
\hline Relative canker length $(\%)^{\mathrm{d}}$ & 100 & $43.0(5.1)$ & $\leq 0.01$ \\
\hline
\end{tabular}

${ }^{a}$ Cut-only control $(n=10)$ and Cut plus $\operatorname{ASM}(n=16)$. SE $=$ standard error For both treatments, fire blight symptoms were removed from trees by pruning. In conjunction with pruning, ASM (15 g a.i./liter) plus $1 \%$ silicone surfactant was applied by foam brush to a 12- to 18 -cm cylinder of symptomless branch tissue below removed cankers (2012 to 2013) or to a 1 -m length of the central trunk of the tree with a hand-held sprayer (2014 to 2016).

${ }^{\mathrm{b}}$ Statistical significance based on two-sample $t$ test; ns = not significant.

${ }^{c}$ Assessed at time of the final pruning of cankers (September or October).

${ }^{\mathrm{d}}$ Within individual experiment, sum of secondary and tertiary pruning cuts (branch weight in kilograms or length in meters) divided by corresponding sum from the cut-only control.

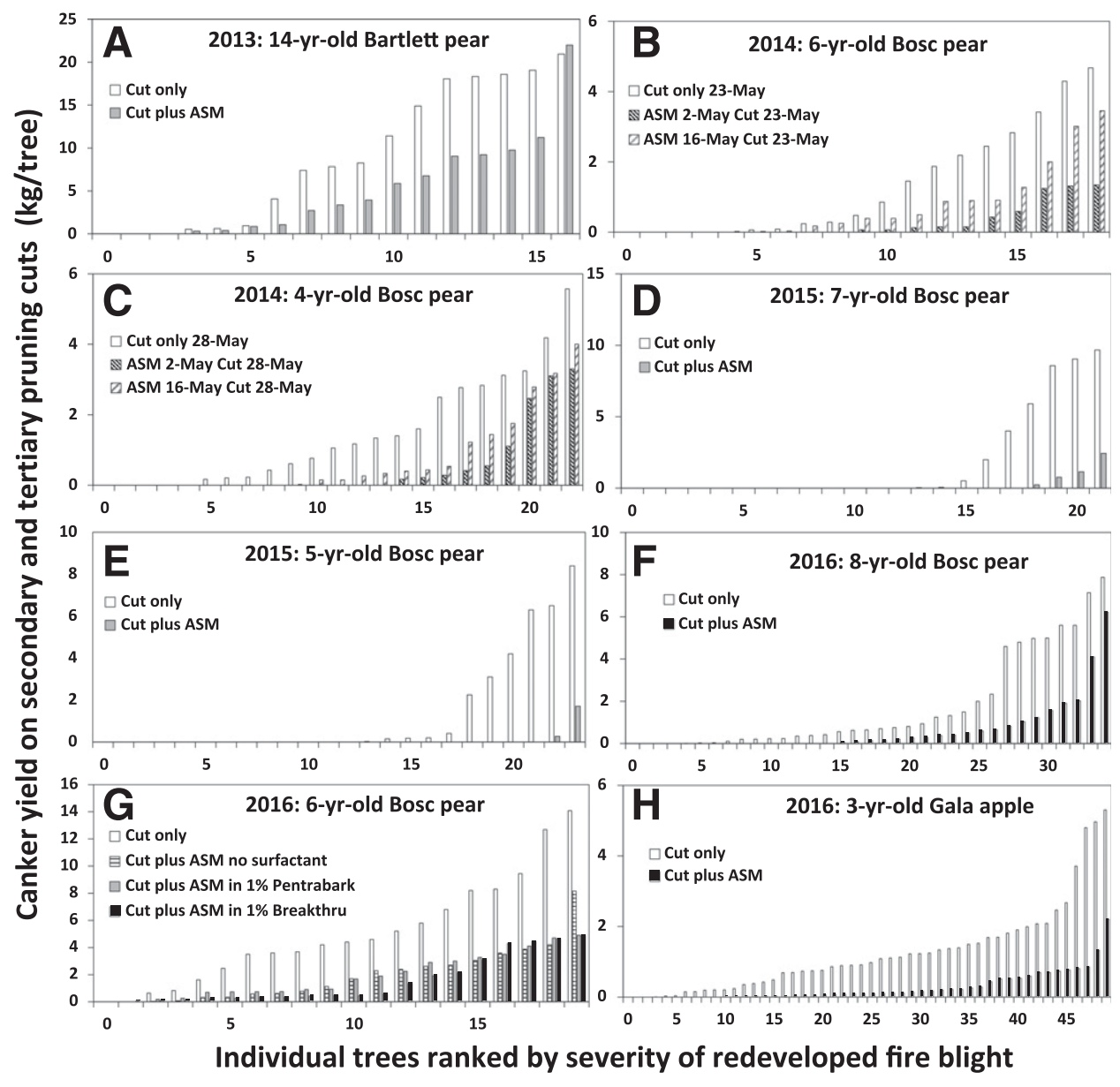

Fig. 1. Effect of an inducer of systemic acquired resistance, acibenzolar-S-methyl (ASM), on the redevelopment of fire blight cankers in 3- to 14-year-old pear and apple trees in diseased field plantings located near Corvallis, OR from 2012 to 2016. Trees were inoculated with the fire blight pathogen in April. Fire blight cankers were cut 15 to $20 \mathrm{~cm}$ below the proximal canker margin in May, near which time ASM was applied as a paint to the cylinder of branch tissue immediately below each pruning cut (2012 and 2013) or to the central trunk region of a tree (2014 to 2016). In some experiments, ASM was applied again in conjunction with secondary pruning of cankers in early summer. Yield (in kilograms) of redeveloped fire blight cankers was measured after secondary and final pruning cuts made in early summer and early autumn. Panels show ranked redeveloped canker yields on individual cut-only trees compared with those that received ASM in conjunction with canker removal. A, fourteenth-leaf Bartlett pear, 2013; B, sixth-leaf Bosc pear, 2014; C, fourth-leaf Bosc pear, 2014; D, seventh-leaf Bosc pear, 2015; E, fifthleaf Bosc pear, 2015; F, eighth-leaf Bosc pear, 2016; G, sixth-leaf Bosc pear, 2016; and H, third-leaf Gala apple, 2016. 
(Johnson and Temple 2016). Beginning in 2014, a change we made in the field studies was to spray ASM onto the central leaders of trees as opposed to brushing the treatment onto 30 to $45 \mathrm{~cm}$ of symptomless branch immediately below each removed canker. Treatment of the central leader suppressed canker redevelopment to a degree similar to the branch treatments but required less time to implement than painting of specific branches. Moreover, in a young tree, maintaining the health of the central leader is critical to its longer-term productivity and may represent more optimal placement of the material. This aspect of SAR therapy (i.e., strength of induction in tissue relative to proximity of induction) should receive additional research effort.

Our results from both the greenhouse (Johnson and Temple 2016) and the field indicate that ASM therapy could be useful in commercial orchards after a fire blight infection event, especially during early years after orchard establishment (ages 2 to 10 years), when clean-up from this disease has proven difficult to manage with therapeutic pruning only. Based on this article and other data (Johnson et al. 2016), the manufacturer of ASM has obtained a federal registration for fire blight control, with therapeutic treatment after canker removal being one of the of labeled uses of the material. In translation of results from small field trials to commercial orchards, we have several concerns that may be resolved only after orchardists have gained experience applying SAR therapy to diseased trees. One concern is that trees in some commercial orchards receive higher inputs of nitrogen fertilizers than we applied to our experimental trees. Nitrogen is a known risk factor contributing to susceptibility of pome trees to fire blight and to frequency of canker redevelopment (van der Zwet and Beer 1992). Consequently, we speculate that there could be a potential interaction between ASM-paint-treatment efficacy and nutritional status of the tree (i.e., ASM therapy would be less effective in a high vigor situation, as has been observed in some pruning situations) (Shtienberg et al. 2003). A second concern is that, in order to obtain a reasonable amount of redeveloped cankers in our small experimental plots, locations of primary pruning cuts on branches were shorter ( 15 to $20 \mathrm{~cm}$ below the canker edge) than some recommendations for removal of fire blight cankers (e.g., up to $30 \mathrm{~cm}$ below the canker edge) (Steiner 2000). Thus, our rate of disease redevelopment may be higher than is typical with a crew of workers experienced with canker removal after a fire blight outbreak, which could devalue ASM therapy in some situations. Note that these first two concerns have expected outcomes that work against each other. A last concern is the effective rate of ASM in a paint suspension compared with the amount legal to apply per acre. After a severe infection event, the amount of ASM applied per acre could exceed the amount allowed by the federal registration if every tree in an orchard was diseased and treated with the material after pruning. Therefore, this technique will be most applicable in well-managed commercial orchards (i.e., those with a preventative spray program for fire blight control during bloom), where it is implemented by orchard workers pruning out cankers at the level of the sporadically distributed, diseased tree.

\section{Acknowledgments}

Actigard 50W and Pentra-Bark surfactant were kindly provided by Syngenta Crop Protection of Greensboro, NC and Quest Products Corporation of Linwood, KS, respectively. Technical assistance was provided by Oregon State University undergraduates L. Bauder, J. Coggins, M. Jackson, and E. Thomas. Partial funding was provided through grants from the Washington Tree Fruit Research Commission and the Pear Bureau Northwest's Fresh Pear Research Committee.

\section{Literature Cited}

Aćimović, S. G., Zeng, Q., McGhee, G. C., Sundin, G. W., and Wise, J. C. 2015. Control of fire blight (Erwinia amylovora) on apple trees with trunk-injected plant resistance inducers and antibiotics and assessment of induction of pathogenesis-related protein genes. Front. Plant Sci. 6:16.

Billing, E. 2011. Fire blight. Why do views on host invasion by Erwinia amylovora differ? Plant Pathol. 60:178-189.
Brisset, M. N., Cesbron, S., Thomson, S. V., and Paulin, J. P. 2000. Acibenzolar-Smethyl induces the accumulation of defence-related enzymes in apple and protects from fire blight. Eur. J. Plant Pathol. 106:529-536.

Clarke, G. G., Hickey, K. D., and Travis, J. W. 1991. Recovery of Erwinia amylovora from excised infected apple shoots and subsequent development of symptoms on pruning stubs in the orchard as influenced by pruning methods. (Abstr.) Phytopathology 81:121.

Covey, R. P., and Fischer, W. R. 1990. Timely cutting of fire blight infections reduces losses. Acta Hortic. 273:351-354.

Francis, M., Redondo, A., Burns, J., and Graham, J. 2009. Soil application of imidacloprid and related SAR-inducing compounds produces effective and persistent control of citrus canker. Eur. J. Plant Pathol. 124:283-292.

Fu, D., and Dong, X. 2013. Systemic acquired resistance: Turning local infection into global defense. Annu. Rev. Phytopathol. 64:839-863.

Garbelotto, M., Schmidt, D. J., and Harnik, T. Y. 2007. Phosphite injections and bark application of phosphite + Pentra-Bark ${ }^{\mathrm{TM}}$ control sudden oak death in coast live oak. Arboricult. Urban For. 33:309-317.

Graham, J. H., and Myers, M. E. 2011. Soil application of SAR inducers imidacloprid, thiamethoxam, and acibenzolar- $S$-methyl for citrus canker control in young grapefruit trees. Plant Dis. 95:725-728.

Johnson, K. B. 2000. Fire blight of apple and pear. Online publication. Plant Health Instruct. doi:10.1094/PHI-I-2000-0726-01

Johnson, K. B., Smith, T. J., Temple, T. N., Gutierrez, E., Elkins, R. E., and Castagnoli, S. P. 2016. Integration of acibenzolar-S-methyl with antibiotics for protection of pear and apple from fire blight caused by Erwinia amylovora. Crop Prot. 88:149-154.

Johnson, K. B., and Stockwell, V. O. 1998. Management of fire blight: A case study in microbial ecology. Annu. Rev. Phytopathol. 36:227-248.

Johnson, K. B., and Temple, T. N. 2016. Comparison of methods of acibenzolar-Smethyl application for post-infection fire blight suppression in pear and apple. Plant Dis. 100:1125-1131.

Koczan, J. M., Lenneman, B. R., McGrath, M. J., and Sundin, G. W. 2011. Cell surface attachment structures contribute to biofilm formation and xylem colonization by Erwinia amylovora. Appl. Environ. Microbiol. 77:7031-7039.

Kuc, J., and Richmond, S. 1977. Aspects of the protection of cucumber against Colletotrichum lagenarium by Colletotrichum lagenarium. Phytopathology 67:533-536.

Maxson-Stein, K., He, S.-Y., Hammerschmidt, R., and Jones, A. L. 2002. Effect of treating apple trees with acibenzolar-S-methyl on fire blight and expression of pathogenesis-related protein genes. Plant Dis. 86:785-790.

Momol, M. T., Norelli, J. L., Piccioni, D. E., Momol, E. A., Gustafson, H. L., Cummins, J. N., and Aldwinckle, H. S. 1998. Internal movement of Erwinia amylovora through symptomless apple scion tissues into the rootstock. Plant Dis. 82:646-650.

Norelli, J. L., Jones, A. L., and Aldwinckle, H. S. 2003. Fire blight management in the twenty-first century: Using new technologies that enhance host resistance in apple. Plant Dis. 87:756-765

Norelli, J. L., Momol, M. T., Aldwinckle, H. S., and DeMarree, A. 1999. Effect of pruning and other orchard factors on the rootstock phase of fire blight. Acta Hortic. 489:509-510

Shtienberg, D., Zilberstaine, M., Oppenheim, D., Levi, S., Shwartz, H., and Kritzman, G. 2003. New considerations for pruning in management of fire blight in pears. Plant Dis. 87:1083-1088.

Steiner, P. W. 2000. Integrated orchard and nursery management for the control of fire blight. Pages 339-358 in: Fire Blight: The Disease and Its Causative Agent, Erwinia amylovora. J. L. Vanneste, ed. CAB International, London.

Stockwell, V. O., Johnson, K. B., and Loper, J. E. 1998. Establishment of bacterial antagonists of Erwinia amylovora on pear and apple blossoms as influenced by inoculum preparation. Phytopathology 88:506-513.

Tally, A., Oostendorp, M., Lawton, K., Staub, T., and Bassi, B. 1999. Commercial development of elicitors of induced resistance to pathogens. Pages 357-370 in Induced Plant Defenses Against Pathogens and Herbivores: Biochemistry, Ecology, and Agriculture. A. A. Agrawal, S. Tuzun, and E. Bent, eds. American Phytopathological Society, St. Paul, MN.

Thomson, S. V. 2000. Epidemiology of fire blight. Pages 9-36 in: Fire Blight: The Disease and Its Causative Agent, Erwinia amylovora. J. L. Vanneste, ed. CAB International, London.

Toussaint, V., and Philion, V. 2008. Natural epidemic of fire blight in a newly planted orchard and effect of pruning on disease development. Acta Hortic. 793:313-320.

van der Zwet, T., and Beer, S. V. 1992. Fire Blight-Its Nature, Prevention, and Control: A Practical Guide to Disease Management. Agric. Inf. Bull. 613. USDA Science and Education Administration, Washington, DC.

Walters, D. R., and Fountaine, J. M. 2009. Practical application of induced resistance to plant diseases: An appraisal of effectiveness under field conditions. J. Agric. Sci. 147:523-535. 